\title{
Tvar - emergentni fenomen i poziv fizike na metafiziku
}

\author{
Marina Novina*, Nikola Stanković**
}

\begin{abstract}
Sažetak
Pitanje emergencije složenosti, nesvodive na prethodno u prirodi, jedno je od aktualnijih pitanja brojnih suvremenih znanstvenih disciplina i filozofije. Samo pitanje emergencije složenosti grana se u tri temeljna pitanja (na tri tzv. faze emergencije): odakle uopće nešto, odakle život i odakle svijest? Prvu fazu emergencije složenosti, u koju spada pokušaj razumijevanja tvari, pokušali su razumjeti već prvi filozofi koji su tvar smatrali objektom proučavanja i fizike i metafizike. Suvremena pak znanost na pitanje tvari pokušava dati odgovor iz konteksta fizike. No, ta istraživanja otkrila su začuđujuća obilježja tvari koja vode prema zaključku da je njezina redukcija (na jedno) neostvariva i da su i tvar i njezina, dosad poznata, tzv. fundamentalna razina, složene. Ta spoznaja upućuje na zaključak da je razumijevanje materijalnog svijeta pitanje fizike i metafizike, tj. da pojam emergencije pretpostavlja i zahtijeva razumijevanje i na ontološkoj razini. U tom smislu važno je u pojedinosti vidjeti na koje zaključke upućuje suvremeno razumijevanje tvari. Ovaj rad želi istražiti osnovna obilježja emergencije i složenosti, odnosno emergencije složenosti, posebno prve faze emergencije te suvremeno razumijevanje tvari, kako bi se na temelju tog uvida pokušalo uobličiti odgovor na pitanje: što tvar jest? Ako je riječ o emergentnom fenomenu, što to znači za razumijevanje zbilje i emergencije složenosti općenito?

Ključne riječi: emergencija, složenost, emergencija složenosti, prva faza emergencije složenosti, tvar, emergentni fenomen, ontologija, kauzalnost
\end{abstract}

* Marina Novina, mag. phil., mag. soc., Fakultet filozofije i religijskih znanosti Sveučilišta u Zagrebu. Adresa: Jordanovac 110, 10000 Zagreb, Hrvatska. E-pošta: marina.novina@ffrz.hr

** Prof. dr. sc. Nikola Stanković, u miru, Fakultet filozofije i religijskih znanosti Sveučilišta u Zagrebu. Adresa: Jordanovac 110, 10000 Zagreb, Hrvatska. E-pošta: snikola@ffrz.hr 


\section{Uvod}

Fenomeni emergencije i složenosti, odnosno fenomen emergencije složenosti (emergance of complexity) $)^{1}$ iznimno je aktualno pitanje u suvremenom znanstvenom diskursu u kontekstima zaista brojnih znanstvenih disciplina, od psihologije, sociologije, biologije, kemije, fizike, kozmologije pa sve do matematike i, naravno, filozofije. Razlog te aktualnosti proizlazi iz činjenice koja je davno uočena: priroda je složen sustav. U odnosu na taj sustav uzdižu se tri temeljne zagonetke (tzv. pitanja ili faze emergencije). Prva, odakle uopće nešto (jer svako „nešto“ — biće u prirodi - već jest „nešto“ složeno)? Druga, odakle život i treća, odakle svijest? Kako pak čitamo: »emergencija je svojstvo i kompjuterskih modela i sustava koji se modelira. Tako priroda sa svake razine uzdiže nove strukture i obrasce ponašanja izabrane iz velike domene mogućega « (Morowitz, 2002, 14). ${ }^{2}$ Isto tako, uglavnom se smatra da je fenomen emergencije filozofima postao zanimljiv tek tamo s J. S. Millom 1843. (Bedau i Humphreys, 2008, 11). No, u netom izrečenom slutimo stari problem odnosa dijelova i cjeline, poznat još sa stranica Aristotelove Metafizike (Aristotel, 2001, 153-155; 1023b 25-1024a 10). ${ }^{3}$ Taj problem otvara cijeli niz epistemoloških i metafizičkih pitanja, na razini pitanja o biću i o temeljnoj strukturi zbilje, u kontekstu fizike i metafizike. Preciznije, pitanje, potaknuto radovima filozofa prije Sokrata, glasilo je: postoji li ipak neka temeljna sastavnica sveg mnoštva, neki temelj, neko jedno prvo počelo svega ili je priroda i na fundamentalnoj razini zaista mnoštvena i složena?

Dakle, složenost kozmosa nikada nije bila upitna, no kako tu složenost razumjeti i može li se ipak doći do nekog ne-složenog temelja, oduvijek je bilo veliko pitanje. U tom smislu, pod emergencijom se razumije pokušaj otkrivanja svojstva cjeline iz razumijevanja dijelova, što znači pokušati spoznati kako složenost izrasta u složenim sustavima, odnosno kako makroskopski fenomeni izrastaju iz mikroskopskih interakcija. Redukcija pak cjelinu svodi na razumijevanje dijelova, odnosno na ideju: "pronađimo fundamentalne dijelove i zakone« (Fromm, 2004, 5). Kao i pitanje složenosti i ideja redukcije poznata je još iz vremena prvih filozofa i traganja za prvim počelom svega. Bilo je to pitanje metafizike, fizike ili pak filozofije prirode. Do istog zaključka dovodi i suvremena znanost. Naime, u vrijeme razvoja pozitivističkih ideja redukcija je postala velika tendencija znanosti koja je odgovore na pitanja prve faze emergencije složenosti pokušala ponuditi isključivo iz konteksta fizike. No, upravo je suvremena znanost na sofisticiranim

1 Među prijevodima termina u literaturi na hrvatskom jeziku možemo naći i oblike kao što su „,izrastanje složenosti“ ili „emergencija kompleksnosti“ ili neku od sličnih kombinacija. Gornji prijevod smatramo najbližim izvornomu značenju termina i najprikladnijim prijevodom na hrvatski jezik. No, još je jedna napomena koju treba nadodati. Naime, u literaturi (uglavnom na stranim jezicima) problem složenosti i emergencije tematiziraju se i odvojeno, sasvim je to razvidno iz tekstova na koje referiramo i u ovom radu. Ipak, činjenica je da je fenomen emergencije neodvojiv od konteksta složenosti u kojem je prepoznat (Morowitz, 2002, 2).

2 Svi citati u ovom radu iz literature na stranom jeziku prijevodi su autora članka.

3 Pri referiranju na Aristotelova ili Platonova djela u unutartekstnoj citatnici, uz podatke o autoru, godini izdanja i stranici, donosimo i tradicionalnu referencu na odgovarajući redak u izvorniku. 
razinama proučavanja prirode, na razini razumijevanja tvari, došla do pomalo začuđujućih „obilježja“ fundamentalne razine stvarnosti. Došla je do spoznaje da je potpuna redukcija neostvariva jer iznimna složenost postoji i na samoj fundamentalnoj razini prirode (Zichichi, 2015, 60). Ta spoznaja otvara neka stara pitanja, a među njima i ono: što je tvar? U tom smislu, cilj je ovog rada utvrditi što se može zaključiti iz suvremenog znanstvenog razumijevanja tvari: (1) što je to tvar i (2) što suvremeno razumijevanje tvari znači za pitanje emergencije složenosti?

Da bismo mogli odgovoriti na istaknuta pitanja, potrebno je izdašnije reći kako se određuju problemi emergencije i složenosti, odnosno što se podrazumijeva pod emergencijom složenosti i njezinim temeljnim obilježjima. S obzirom na temeljna pitanja emergencije složenosti ovaj se rad usredotočuje na prvu fazu emergencije složenosti, koju smatra najzagonetnijom i najznačajnijom, a u čijem se središtu nalazi pokušaj razumijevanja tvari. U tom smislu, ovaj rad istražuje temeljna obilježja suvremenog razumijevanja tvari, kako bi iz njih izvukao odgovor na pitanje što je tvar, odnosno je li riječ o emergentnom fenomenu. Ako jest, onda se postavlja pitanje: govori li nam to išta za razumijevanje emergencije složenosti općenito?

\section{Fenomen emergencije složenosti}

Zagonetnost i poteškoće oko pitanja emergencije nagovještava već sam termin. Lijepo je to u jednom od pokušaja preciznijeg određenja emergencije na hrvatskom jeziku istaknuo sociolog Krešimir Žažar:

Značenje emergencije nije jednostavno odrediti. Etimologija riječi je latinska i uključuje riječi e $(x)+$ mergere [...]. Glagol emergere najčešće se prevodi kao izroniti, pomoliti se, isplivati, izići van, a uključuje dodatne značenjske razine kao što su podignuti se, izdignuti se, doći do čega te oporaviti se, ohrabriti se i niz srodnih značenja [...] emergencija se u prvom redu prevodi kao izvaditi, odnosno izroniti [...]. Latinska imenica emergentia u hrvatskom jeziku ekvivalent pronalazi u 'događaji, najčešće neočekivani, zapletaji' [...]. Predstavljeni prijevodi, u prvom redu riječi izroniti i isplivati uz naznaku da je riječ o pojavi neočekivanih događaja, adekvatno predstavljaju semantički izraz odgovarajućeg pojma kao dijela znanstvenog diskursa (Žažar, 2016, 52).

Možemo reći da John H. Holland, psiholog i jedan od prvih znanstvenika koji se bavio genetičkim algoritmima, s pravom kaže da je emergencija, unatoč sveprisutnosti i važnosti, zagonetna i nejasna tema, kojoj se više divi no što ju se analizira (Morowitz, 2002, 25). Američki je biofizičar Harold J. Morwitz, u tom smislu, izdvojio čak dvadeset osam razina emergencije, od pitanja odakle išta do pitanja nastanka elemenata, planeta, živih bića, neurona, jezika, kulture, filozofije itd. (Morowitz, 2002, 25-38). Tako pak postaje sasvim razvidno koliko je zahtjevan svaki pokušaj preciznog određenja emergencije. Naime,

po definiciji, emergencija transcendira svaku samostalnu disciplinu. Na nedavnom međunarodnom kolokviju o teorijama emergencije, svaki je znanstvenik zamoljen da definira emergenciju, i svaki je ponudio definiciju termina iz svojeg posebnog područja istraživanja; fizičar je odredio emergenciju kao produkt vremenski-invarijan- 
tnih prirodnih zakona; biolog je prezentirao emergenciju kao posljedicu prirodne povijesti; neuroznanstvenik je govorio primarno o 'stvarima koje emergiraju iz mozgova'; a inženjeri su konstruirali emergenciju u terminima novih stvari koje možemo izgraditi ili stvoriti. Svaka je od tih definicija dio, ali nijedna samostalno ne može biti izvor opće teorije emergencije (Clayton, 2004, 580).

Usuglašena definicija emergencije, dakle, ne postoji, a s obzirom na rečeno jasno je da oblikovanje neke jednoznačne definicije nikako nije jednostavno. Ipak, smatra se da među temeljna obilježja fenomena emergencije spadaju: nemogućnost redukcije, nemogućnost predviđanja, neobjašnjivost, konceptualna novost i holizam. Ta se obilježja često smatraju »refleksijama dublje ontološke novine emergentnih fenomena. Ta ontološka interpretacija emergencije emergente smatra izvorno novim obilježjima svijeta, koji izrastaju iz njega, ali su isto tako u nekom smislu odijeljeni od fundamentalnih aspekata sustava« (Bedau i Humphreys, 2008, 11).

No ni određenje složenosti nije tako jednostavna stvar. Naime, talijanski fizičar Antonino Zichichi navodi sedam različitih definicija složenosti. Najjednostavnija među njima složenost određuje kao suprotnost jednostavnosti, i tako pokazuje da je i sama složenost iznimno loše određena (Zichichi, 2015, 58-59). Kozmolog i matematičar, jedan od recentnijih autora glede pitanja složenosti, George R. F. Elllis, pak, govoreći o istinskoj složenosti, odnosno složenim sustavima, ističe sljedeće: »istinska složenost uključuje velike količine informacija i hijerarhijski organiziranih struktura koje procesuiraju informacije na svrhovit način [...] njihovo ponašanje djeluje svrhovito« (Ellis, 2004, 607). Uz to, a uzevši u obzir do sada rečeno, možemo navesti da:

1) sustavi višeg stupnja složenosti pojavljuju se kao nove konfiguracije entiteta niže razine; 2) atributi entiteta višeg nivoa izviru iz svojstava entiteta nižeg reda pri čemu se neki fenomeni višeg reda pojavljuju kao emergentni dok drugi predstavljaju rezultante; 3) emergentna svojstva ne mogu se predicirati iz početnih uvjeta djelatnih u danom razmatranom sustavu; 4) emergentna svojstva se ne mogu objasniti na temelju bazičnih uvjeta u danom sustavu, niti se na njih mogu svesti; 5) emergentni fenomeni imaju radikalno novu kauzalnu moć raznorodnu u relaciji spram njenih konstitutivnih dijelova (Žažar, 2016, 54).

Sasvim je razvidno da je fenomen emergencije složenosti, baš kao što sam termin nagovještava, višeslojno i iznimno složeno pitanje koje se proteže od fizike do metafizike. Naime, fenomen emergencije složenosti pitanje je o temeljnim svojstvima entiteta, ali i o njihovoj zbiljnosti, odnosno o ontološkom statusu emergenata, a svakako o kauzalnosti, o odnosu dijelova i cjeline, ali i o čovjekovoj mogućnosti da spozna dijelove, odnosno cjelinu. Stoga, ističe Ellis, s obzirom na složenost koja postoji postavljaju se pitanja: »Što je zbiljsko? «, odnosno, »Što zapravo postoji? «, ali i »Kakve vrste kauzalnosti nalazimo u tim strukturama? « (Ellis, 2004, 607). Tako se pak temeljna pitanja pokazuju kao pitanja emergencije. To je pitanje kako globalne strukture i fenomeni iznenada izrastaju iz jednostavnih lokalnih interakcija te, nadalje, pitanja vezana uz samo-organizaciju, kooperaciju, specijalizaciju te uključivanje i ugrađivanje (Fromm, 2004, 8). 
Primjeri istinski složenih sustava su: »molekularna biologija, životinjski i ljudski mozak, jezik i sustav simbola, individualno ljudsko ponašanje, socijalni i ekonomski sustav, digitalni sustavi i biosfera « (Ellis, 2004, 607). Dakle, u odnosu na prirodu uzetu u cjelini, a s obzirom na to da složenost postoji na svim njezinim razinama, fenomen emergencije složenosti možemo promatrati, i o njemu promišljati, u tri temeljna konteksta: prvi, onaj fizike koji se odnosi na pitanje nastanka svemira; drugi, kontekst biologije koji postavlja pitanje o pojavljivanju života; i treći, kontekst neuropsihologije koji se suočava s pitanjem pojavljivanja svijesti (Zichichi, 2015, 83). Drugim riječima, možemo reći da govor o emergenciji složenosti zahtijeva prolazak kroz najmanje tri faze. Prvu fazu nalazimo na području fizike, a uključuje emergenciju klasičnih fenomena kvantnog svijeta i emergenciju kemijskih svojstava kroz molekularnu strukturu. Druga faza odnosi se na biologiju, odnosno pojavu bioloških procesa, a treća faza uključuje govor o pojavi svijesti. No na te tri razine neki, kaže suvremeni filozof znanosti Philip D. Clayton, dodaju i četvrtu, metafizičku, kojom se sugerira da pravi uzroci emergencije u prirodi transcendiraju odnosno leže iza prirode (Clayton, 2004, 578). Mi smatramo da bez te faze nema razumijevanja ni jedne faze emergencije i da je to iznimno dobro vidljivo na fundamentalnoj razini prirode. Stoga, ovaj se rad nadalje usredotočuje na kontekst prve faze emergencije složenosti i sagledava implicira li prva faza emergencije, odnosno suvremeno razumijevanje tvari, četvrtu fazu emergencije, odnosno ontološku razinu, i na koji način.

\section{Prva faza emergencije složenosti}

Za prvu fazu emergencije složenosti možemo reći da je zagonetnija od svih ostalih. Naime, u toj se fazi emergencije jasno pokazuje nešto što se može promatrati pod vidikom fizike i metafizike. Ne bi s tom tvrdnjom bilo problema da, s razvojem pozitivizma, znanost svoj pogled nije usredotočila samo na jednu stranu. No, dobro je to uočio Poincaré u jednom drugom kontekstu kada kaže »znanost ne može biti dovoljna zato što vidi samo jedan dio čovjeka, ili, ako više volite, ona vidi sve, ali vidi sve s iste strane« (Poincaré, 1989, 195). Ipak, suvremena je znanost, nakon neuspjeha pozitivizma, nakon teorije relativnosti, nakon kvantne revolucije, pomalo prisiljena početi razmišljati i o toj drugoj strani, a pitanje o toj drugoj strani očito se pojavljuje na svim razinama zbilje. Osobito je to pak očito u prvoj fazi emergencije složenosti.

Pogledamo li prvu fazu emergencije složenosti kroz pitanja koja se nameću, uočavamo da je teško reći koje je od pitanja u toj fazi zagonetnije. Možda na koncu ipak ono metafizičko koje pita: odakle uopće išta? Na to metafizičko pitanje odgovor su pokušale ponuditi sve kulture, religije i filozofija. Danas pak ima onih koji smatraju da uspješne odgovore na pitanje odakle išta, odnosno na pitanje stvaranja, dobivamo iznimno dobar odgovor iz znanstvenog konteksta. Osobito iz suvremene kozmologije, u obliku teorije velikog praska ili ideje multiverzuma. Ipak, valja odmah istaknuti kako je to sasvim netočna tvrdnja. Naime, teorija velikog praska u biti ne govori ništa o nastanku univerzuma, niti može. 
Teorija velikoga praska govori o razvoju univerzuma od trenutka velikog praska do tzv. Planckove ere, do trenutka $10^{-43}$ s, a tada se naše tehnološke mogućnosti suočavaju sa svojim granicama. Singularnost je točka u kojoj se lomi naša opažajna spoznajna moć. S druge strane ideja multiverzuma govori o tome koliko je vjerojatno da univerzum poput našega postoji, tj. da naš univerzum uopće nije nevjerojatan (poseban), nego samo jedna od mnogih mogućnosti, nikakva posebnost. No odgovor na pitanje odakle ansambl mogućnosti ideja multiverzuma ne nudi, niti može ponuditi. Time postaje sasvim očito da se u prvoj fazi emergencije složenosti nužno pojavljuje veliko metafizičko pitanje, pitanje početka, za koje se čini kako je ono jedno od središnjih pitanja za religiju, filozofiju, a očito i znanost (Morowitz, 2002, 26).

No, čini se da je u toj prvoj fazi emergencije složenosti jednako zagonetno ono drugo pitanje, sa strane fizike: što je uopće nešto? Odnosno, što je to nešto u temelju svega? I na to je pitanje davno pokušala odgovoriti filozofija, ali osobito mu se posvetila suvremena znanost. U srži te zagonetke nalazi se pokušaj razumijevanja tvari, jednog od temeljnih pojmova zapadne filozofije i suvremene znanosti, a koji, iako je jedan od sveprisutnih i prijeko potrebnih pojmova, još uvijek predstavlja veliku zagonetku. Iako ni to nije neki krajnji odgovor, jer je pitanje emergentnih fenomena još uvijek zagonetna i otvorena tema (Bedau i Humphreys, 2008, 17), ipak čini se da detaljniji uvid u suvremeno razumijevanje tvari samu tvar otkriva kao emergentni fenomen koji se ne može razumjeti ,jednostrano“. Drugim riječima, složenost implicira fiziku i metafiziku i to proizlazi upravo iz zaključaka suvremene znanosti o obilježjima prve faze emergencije složenosti i iz uvida u strukturu tvari.

\section{Tvar-emergentni fenomen}

Pitanje tvari jedno je od najstarijih filozofijskih i znanstvenih pitanja s iznimno složenom poviješću koja se pokazuje važnom za razumijevanje sadašnjeg stanja. Da je tvar emergentni fenomen koji za razumijevanje implicira fizikalni i metafizički aspekt, očito je već od prvih pa do suvremenih razumijevanja tvari. Prvo je potrebno napomenuti, a drugo izložiti. Naime, već su prvi filozofi za prva počela svega ( $\dot{\rho} \rho \chi \alpha$; arhai), za temeljne sastavnice zbilje postavili tvar: vodu, vatru, zrak. Jedna od novosti koju su donijeli prvi filozofi zasigurno je bila pokušaj razumijevanja prirode iz nje same. To je bila velika novost i dobar poticaj razvoju znanosti. Ali ta ih je novost dovela u slijepu ulicu u kojoj mnogi stoje i danas. Naime, da se pukim nabrajanjem tvarnih počela i uzroka ne može doći do valjanih odgovora na pitanja „početaka“ prepoznao je već Platon, odnosno Sokrat koji predlaže deutros plous (Platon, 1996, 103-112; 96a-102), ${ }^{4}$ tzv. bijeg u mišljenje. Platon je u Timeju ipak bio nešto precizniji u određenju same tvari pa

4 O mjestu 98d-99d pisao je i Leibniz. On kaže da ni Descartes ni Spinoza nisu primijetili ono što je uočio Sokrat, tj. da se glavni stavovi fizike izvode iz pojma duhovnog uzroka, nego puke uvjete i oruđe brkaju s istinskim uzrokom (Leibniz, 1980, 24-26). 
je istaknuo da je tvar uvijek u procesu nastajanja — ona je materija odnosno majka i prihvatiteljica koja u sebe može prihvatiti različite oblike, a njezini najmanji dijelovi su geometrijski oblici koji se mogu pretvoriti jedan u drugoga jer im se u temelju nalazi trokut. Dakle, Platon nam kaže, želimo li spoznati što je tvar, da bi na koncu spoznali i što je zbilja, moramo se pustiti mrtve tvari i proniknuti u njezinu matematičku strukturu, koja je puno bliža istinskoj zbilji — za Platona svijetu ideja (Heisenberg, 1997, 52). No, istu poteškoću, da puko nabrajanje materijalnih uzroka nije dovoljno, uočio je i Aristotel. Stoga je prigovarao prvim filozofima da se nisu maknuli dalje od prvih počela kao tvarnih osnova, odnosno poistovjetili su mrtvu tvar s prirodom ( $\varphi v ́ \sigma \iota \varsigma ;$ physis) čime su nešto neživo i pasivno poistovjetili s nečim živim i aktivnim (Pavlović, 1978, 201-202). Štoviše, ono

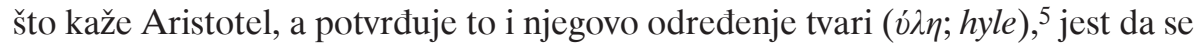
ni prirodu, ali ni tvar ne može razumjeti isključivo kao mrtvu tvar. Dakle, tvar je građa, ali nije samo građa, tj. materia secunda koja je ono opažanju spoznatljivo, ona je i podmet, tj. pratvar (materia prima), podloga, nositelj, svake promjene, ali i bez lika i oblika, opažanju nedostupna, lišena svih pozitivnih odredbi (Robinson, 1974). Tvar tako jest nešto „ovo“, ali nešto dinamično čiju narav možemo upoznati samo ako uzmemo u obzir fiziku i metafiziku, ${ }^{6}$ i promjenjivo i nepromjenjivo.

Tijekom povijesti pojam „tvar“ u različitim filozofijsko-znanstvenim kontekstima poprimao je različita značenja. Ipak, sva su ta značenja, a osobito netom istaknuta, »do izvjesnog stupnja još živa u današnjoj znanosti kad upotrebljavamo riječ 'tvar' " (Heisenberg, 1997, 117), potvrđuje to upravo suvremeno znanstveno razumijevanje tvari. Naime, suvremeni pokušaji određenja svojstava, odnosno strukture tvari jasno upućuju na dvije netom spomenute linije filozofijskih promišljanja. Naime, na tragu Platonova razmišljanja o tvari danas se smatra da »izvjesne simetrije zapravo igraju vrlo važnu ulogu u teoriji elementarnih čestica « (Heisenberg, 1997, 132). U kontekstu pak spoznaje da su energija i tvar različiti oblici iste građe, suvremena je znanost na tragu Aristotelova razumijevanja tvari. A tvar je za Aristotela bila potencija, tj. mogućnost koju »treba usporediti s našim pojmom energije; energija se pojavljuje kao tvarna realnost kroz oblik onda kada se stvori elementarna čestica « (Heisenberg, 1997, 127). Te bi spoznaje trebale voditi izravno do zaključka da je tvar, baš kako su isticali i Platon i Aristotel, takav fenomen da za njegovo razumijevanje nije dovoljno puko nabrajanje i uvid u strukturu mrtve tvari, odnosno da je tvar fenomen fizičke i metafizičke naravi.

Drugim riječima i detaljnije gledano, redukcionističko-pozitivistički pokušaj svođenja zbilje na fundamentalnu razinu doveo je do više neočekivanih spoznaja. Kako naglašava Ernan McMullin, poznati filozof znanosti, došlo je do ubrzane

5 Tvar je za Aristotela „ovo“, tj. podmet, „nešto prema čemu“ (Aristotel, 2001, 9; 983a 30; Aristotel, 1988, 36; 194b 8-9). Heinemann stoga komentira da je tvar pojam relacije (Heinemann, 2009, 47). Inače, najvjerojatnije je da upravo u prvoj knjizi Aristotelove Metafizike nalazimo prvo sistematično istraživanje pojma tvari u antici (McMullin, 1965, 3).

6 Detaljnije o razumijevanju tvari kroz povijest vidi: McMullin, 1965; McMullin, 2010, a o shvaćanju prirode vidi: Collingwood, 1945; Naddaf, 2006. 
dematerijalizacije tvari uzrokovane razvojem teorije relativnosti, kvantne mehanike i kozmologije (teorija velikoga praska) (McMullin, 2010, 23). ${ }^{7}$ Prvo, kada je Einstein razvijao teoriju relativnosti i spojio poznata načela očuvanja mase i energije u $\mathrm{E}=\mathrm{mc}^{2}$, zapravo je još jednom otvorio pitanje tvari. ${ }^{8}$ Naime, ako masa i energija ostaju očuvane u fizičkim procesima i u prikladnim okolnostima dana količina energije može biti transformirana u odgovarajuću količinu tvari, što je onda tvar? Ako se pod masom podrazumijeva količina tvari kako je to formulirao Newton, a tako se držalo, a zračenje nema mase, onda ni tvar više nema kvalifikacije tvari. Odnosno, Einsteinovom jednadžbom započinje dematerijalizacija fizičke zbilje, tj. dovođenje u pitanje materijalizma (McMullin, 2010, 24), čime se ujedno postavlja temelj za razumijevanje tvari kao emergentnog fenomena. Naime, materijalizam je formiran na pet fundamentalnih hipoteza:

(1) Tvar je fundamentalni konstituent prirodnog svijeta. (2) Sile djeluju na tvar. (3) Fundamentalne tvarne čestice ili 'atomi' — zajedno s fundamentalnim fizičkim silama, što god da se ispostavi da su one - određuju gibanje objekata u prirodi. Dakle, materijalizam implicira determinizam. (4) Svi složeni objekti koje opažamo u prirodnom svijetu su agregati tih fundamentalnih čestica, i njihovo gibanje i ponašanje na koncu može biti shvaćeno u terminima djelovanja fundamentalnih fizičkih sila na njih. Ne postoji ništa što ne bi bilo produkt tih čestica i sila. Dakle, ne postoje neke posebne biološke sile (vitalizam ili ,entelehija“), nikakve sile svijesti (dualizam), i nikakve duhovne sile (ono što je postalo poznato kao supernaturalizam). Stoga, materijalizam implicira isključenje dualizma, kauzalnost odozgo prema dolje [...] i božanske aktivnosti. (5) Materijalizam je ontološka pozicija s obzirom na to da određuje koja vrsta stvari postoji ili ne postoji. Ali isto tako može postati teza kojom se određuje što se može smatrati ili ne smatrati znanstvenim objašnjenjem. U kombinaciji sa znanstvenim redukcionizmom, primjerice, zahtijeva da sva znanstvena objašnjenja u konačnici budu svediva na objašnjenja fundamentalne fizike (Clayton, 2010, 38-39).

Svakako, novosti do kojih je dovela Einsteinova teorija relativnosti vode do dva moguća rješenja u vezi s tvari, odnosno u vezi s temeljnim sastavnicama materijalne zbilje: ili kombinacija masa-energija ima ulogu mase (kako je shvaćena u kontekstu mehanike) ili tvar može biti svedena na tromu masu, odnosno realnost ima dva temeljna konstituenta: tvar i energiju (McMullin, 2010, 25). Oba fenomena još uvijek predstavljaju otvorena znanstveno-filozofijska pitanja, koja upućuju na zaključak da se odgovori ne mogu naći samo u okvirima materijalnoga. Odgovori se moraju tražiti i iz fizikalne i iz ontološke perspektive. Ali to je bio tek početak otkrivanja neobičnih obilježja tvari.

Nadalje, i kao drugo, pitanje tvari dodatno je produbljeno utvrđivanjem dvojnog ponašanja svjetlosti. Naime, do početka 20. st. postojale su dvije teorije o naravi svjetlosti, jedna je tvrdila da je svjetlost čestica, a druga da je val, a tada

7 Posljednja, odnosno kozmologija, je u posljednjem stoljeću otvorila brojna nova pitanja: antitvar, tamna tvar, tamna energija, vakuum, gravitacija itd. Sve su to još uvijek otvorena pitanja i uglavnom hipoteze koje čekaju na „empirijsku“ potvrdu. Ta pitanja potvrđuju svu zagonetnost tvari, no s obzirom na to da se suvremena znanost o njima nije izjasnila, u njih ovdje nećemo ulaziti.

8 Detaljnije o filozofijskim implikacijama teorije relativnosti u vezi s razumijevanjem tvari vidi: Cassirer, 1998, 55-71. 
se utvrdilo da svjetlost zapravo ima dvojnu prirodu. To je, kaže McMullin, zasigurno bilo dobro za svjetlost, ali ne i za tvar jer je ta spoznaja upućivala na valnu prirodu tvari. To je prvi uočio i teorijski postulirao De Broglie, koji je protegnuo dualizam između tog valnog i čestičnog opisa na elementarne čestice, odnosno na subatomsku razinu (McMullin, 2010, 26; Heisenberg, 1997, 27). Drugim riječima, temeljne sastavnice tvari (razne čestice) više nisu pasivne i tvar više nije samo čestica, nego ima i svojstva vala. Proturječje dvojne prirode tvari našlo je rješenje u valnoj funkciji, odnosno u ideji vala vjerojatnosti. No, vjerojatnost $u$ matematici ili statističkoj mehanici predstavlja iskaz o našem stupnju poznavanja činjenične situacije. ${ }^{9}$ »Ali val vjerojatnosti [...] sadržavao je više od toga. On je značio nešto kao sklonost nekom određenom događaju. On je značio kvantita-

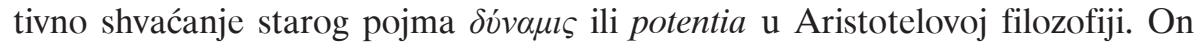
je uveo čudnu vrstu fizičke stvarnosti koja stoji u sredini između mogućnosti i zbiljnosti« (Heisenberg, 1997, 29-30). Možemo reći, tvar se ponovo pokazuje, kao i Aristotelu, kao fizikalno i metafizičko pitanje. No, uz to, val vjerojatnosti upućuje i na matematički karakter kvantne teorija, a matematički karakter upućuje na još jednu razinu napuštanja materijalizma i na isti zaključak: metafizička interpretacija je nužna. Posljedice primjenjivosti matematike u znanosti (matematika je jezik današnje znanosti, esencijalna za fiziku, i ima veliku ulogu u otkriću novih fenomena) dobro je uočio i inače materijalist W. Quine, koji kaže da nam »neodvojivost matematike i znanosti daju dobre temelje za vjerovanje u objektivno postojanje matematičkih entiteta « (Byl, 2007, 80). Štoviše, »S obzirom na to da se znanost bavi realnima objektima, čini se da se i matematika mora baviti realnim objektima. To se još više odnosi na one koji pristaju uz realističko viđenje znanstvenih teorija. Kako znanstvene teorije mogu biti istinite osim ako matematika na koju se oslanjaju (the underlying mathematics) nije istinita? «(Byl, 2007, 80). Naime, ako je matematika samo naša konstrukcija, bilo bi zaista čudno da matematika toliko dobro opisuje prirodu i još više nešto tako složeno kao što je mikro razina, odnosno tvar. Zaključak je jednostavan, ističe Ellis, »svijet je zaista fundamentalno matematičke konstrukcije, i sva tvar je svugdje identična po svojstvima« (Ellis, 2004, 629).

Drugim riječima, suvremeno razumijevanje tvari vodi nas do zaključka da su Platon s idejom matematičke strukture tvari i Aristotel s idejom tvari kao potencije, odnosno prve tvari kao podloge, sasvim primjereno tvar smatrali pitanjem fizike i metafizike. Ellis predlaže četiri razine (razine složenosti) u potpunosti kompatibilne s tzv. fazama emergencije složenosti: a) tvar i sile, b) svijest, c) fi-

9 Vjerojatnost je omjer povoljnih slučajeva događaja u odnosu na ukupan broj mogućih događaja. No, na poteškoće u razumijevanju vjerojatnosti uputio je Poincaré koji kaže: »Sam naziv račun vjerojatnosti je paradoks: vjerojatnost, nasuprot izvjesnosti, jest ono što ne znamo, a kako možemo računati ono što ne poznajemo? «(Poincaré, 1989, 136). Stoga je za razumijevanje zbilje neupitna velika važnost filozofije i uloga kauzalnosti, osobito ako se oslanjamo na račun vjerojatnosti, jer sigurnost između odabira konvencija daje nam jedino načelo dovoljnog razloga, a ono se najčešće otkriva kao vjerovanje u neprekinutost, »vjerovanje koje bi bilo teško opravdati apodiktičkim zaključivanjem, ali bez kojega bi svaka znanost bila nemoguća (Poincaré, 1989, 154). 
zičke i biološke mogućnosti i d) matematička stvarnost. Te razine složenosti predstavljaju svojevrsna neovisna područja zbilje koja su nama u biti nepoznata, no to nikako ne bi trebao biti argument u prilog njihova nepostojanja (Ellis, 2004, 621630). Narav zbilje i njezine sastavnice metafizičko su pitanje, ontološko pitanje o postojanju materijalnih i nematerijalnih entiteta gdje brojna pitanja ostaju otvorena i često „dohvatljiva“ jedino metafizici, ali ono što je očito i na fizičkoj razini jest da se mogu utvrditi različiti kauzalni utjecaji između različitih razina zbilje. U tom smislu, danas je poznato da je temeljno obilježje strukturalne hijerarhije fizikalnog svijeta djelovanje odozdo prema gore. Drugim riječima, redukcionizam karakterizira ideja kauzalnosti odozdo prema gore, a emergencija pretpostavlja kauzalnost odozgo prema dolje. Upravo potonju vrstu kauzalnosti nalazimo i između raznih razina zbilje i u prvoj fazi emergencije složenosti na razini tvari, kod nukleosinteze velikog praska i kod kvantnih mjerenja. Kod nukleosinteze velikog praska »stopa nuklearnih interakcija ovisi o gustoći i temperaturi medija interakcije. Mikroskopske reakcije koje se odvijaju u ranom univerzumu, dakle i proizvedeni elementi, ovise o stopi širenja univerzuma (određenom Friedmannovom jednadžbom)«(Ellis, 2004, 615). Djelovanje odozgo prema dolje u kvantnim procesima prepoznajemo kao kolaps valne funkcije, odnosno »proces kvantnog mjerenja je djelomično djelovanje odozgo prema dolje kontroliran od motritelja « (Ellis, 2004, 615). Iz svih pitanja koje se otvaraju već u prvoj fazi emergencije pokazuje se da je tvar emergentni fenomen čije razumijevanje pretpostavlja i fiziku i metafiziku, ali i da za sveukupnu zbilju može biti predložena kauzalna hijerarhija koja počinje i završava s metafizikom koju Ellis imenuje kao „temeljna realnost“. Naime, tim, metafizičkim, temeljnim pitanjima počinje i završava svako pitanje o zbilji koja se neupitno pokazuje kao složeni sustav (Ellis, 2004, 634).

Nadalje, odgovor na proturječja u vezi s pitanjem tvari pokušao je otkloniti Heisenberg načelom neodređenosti i Bohr idejom komplementarnosti. U tom smislu Heisenberg kaže sljedeće:

ustanovilo se da nije moguće navesti istovremeno položaj i brzinu neke atomske čestice sa željenom točnošću. Ili se može vrlo točno odrediti položaj, a tada se do određenog stupnja gubi poznavanje brzine zbog upotrebe instrumenta za promatranje; ili, obrnuto, točnim mjerenjem brzine gubi se poznavanje položaja, tako da se pomoću Planckove konstante dobiva donja granica za produkt tih dviju netočnosti. Iz takvog je formuliranja u svakom slučaju jasno da se s pojmovima newtonovske mehanike ne može ići mnogo dalje; jer za proučavanje nekog mehaničkog procesa treba istovremeno točno poznavati baš mjesto i brzinu u određenom trenutku, a baš bi to prema kvantnoj teoriji trebalo biti nemoguće (Heisenberg, 1998, 97 98). ${ }^{10}$

No, uočio je Bohr, upravo ta neodredivost omogućuje komplementarnost. Naime,

različite lako shvatljive slike kojima prikazujemo atomske sisteme doduše potpuno odgovaraju za određene eksperimente, ali se ipak međusobno isključuju. Tako se na primjer Bohrov atom može prikazati kao planetarni sistem u malom: u sredini atom- 
ska jezgra, a izvana elektroni kruže oko te jezgre. Ali za druge eksperimente može biti svrsishodno da sebi predstavimo da je atomska jezgra okružena sistemom stacioniranih valova, pri čemu o frekvenciji valova ovisi zračenje atoma. Konačno se atom može promatrati i kao predmet kemije, može se proračunati toplina njegove reakcije pri spajanju s drugim atomima, ali se u isto vrijeme ne može ništa tvrditi o kretanju elektrona. Te su različite slike dakle točne ako se upotrijebe na pravom mjestu. Ali one proturječe jedna drugoj, i zbog toga se nazivaju međusobno komplementarnima« (Heisenberg, 1998, 98). ${ }^{11}$

Tako se 1927. došlo do neprotuslovnog tumačenja kvantne teorije, koje se često naziva i kopenhagenskim tumačenjem, koje, pojednostavljeno, nalaže sljedeći način razmišljanja: svaki fizikalni eksperiment mora se opisati pojmovima klasične fizike, no primjenjivost tih pojmova ograničena je relacijama neodređenosti (Torretti, 1999, 371; Heisenberg, 1997, 29-33). Kvantna teorija je dakle statističkog karaktera, što govori o nedeterminističkom karakteru mikro razine, odnosno o napuštanju temeljnih hipoteza materijalizma. S druge strane, još je to jedan primjer, otvaranja fundamentalne razine govoru o kauzalnosti odozgo prema dolje. U tom smislu, uz sve spomenute novine, poznati misaoni eksperiment E. Schrödingera upozorio je na jedan važan detalj, tzv. kolaps valne funkcije, koji izravno vodi do trećeg začuđujućeg zaključka: čin opažanja određuje „elemente“ zbilje (Ridely, 2001, 150) što je samo još jedna otvorena razina za govor o kauzalnosti odozgo. Stoga, zaista možemo zaključiti da je tvar u kontekstu suvremene znanosti zadobila sve karakteristike emergentnog fenomena.

Do danas je visokoenergetska fizika, odnosno fizika elementarnih čestica, uspjela »raščlaniti tvar na oko dvije stotine opservabilnih čestica i rezonancija. Na dubljoj, kvarkovskoj razini taj je broj značajno reduciran uvodeći u igru kvarkove, koji su izravno neopservabilni, ali je njihovo postojanje u vezanim stanjima ustanovljeno posredno. Svakoj čestici na bilo kojoj razini strukture pridružuje se kvantno polje « (Zovko, 2002, 61). Suvremena je znanost tako došla i do četvrte začuđujuće spoznaje. Naime, kao što masa nije u potpunosti drugačija od energije, tako ni čestice Newtonove fizike nisu u potpunosti drugačije od privlačnih i odbojnih sila između njih. Upravo suprotno, prema načelima suvremene fizike sve vrste temeljnih čestica, tvari ili energije, moraju se povezati s odgovarajućim modelom interakcije i poljem (sila). Drugim riječima, sve ima dualne aspekte, dualnu prirodu, djelomično je karakterizirano unutarnjom masom ili energijom, a djelomično uzrokom interakcija s okolinom (Ridely, 2001, 150). Dakle, ono do čega je došla kvantna teorija govori nam da

atom nije tvorba dostupna našoj zornoj predodžbi u istom smislu kao neki predmet dnevnog iskustva. [...] Atom ne možemo bez rezerve objektivirati poput neke stvari u prostoru koja se mijenja u vremenu na način koji se dade utvrditi. Dadu se samo objektivirati rezultati pojedinačnih opažanja, no oni nikad ne daju neku savršeno zornu sliku. Iz toga proizlazi da je predodžba realnosti koja je ležala u temelju Newtonove mehanike bila preuska te mora biti nadomještena nečim širim (Heisenberg, 1998, 72-73).

11 Detaljnije vidi: Torretti, 1999, 367-373. 
Nakon spomenutih spoznaja brojni su došli do zaključka da je stvarnost koja nas okružuje iluzija i da o njoj ni ne možemo ništa reći. No, nakon svega rečenog to se čini kao zaista čudan zaključak. Prije bi se moglo zaključiti da je pogreška pokušavati svesti zbilju isključivo na mrtvu tvar, a potvrđuju nam to složeni sustavi odnosno emergentni fenomeni. Dakle, još jednom, nepoznavanje naravi postojanja nikako nije dobar argument za zaključak na iluziju. Upravo tvar, koja je trebala biti temelj materijalizma, pokazala se kao emergentni fenomen koji poziva na susret fizike s metafizikom, ali nikako i najmanje s iluzijom. Uz to, čini se i sljedeće, naime ukoliko načelo neodređenosti, koje je jedna od temeljnih karakteristika fundamentalne razine emergencije, stvara uvjete za komplementarnosti, koja ujedno poziva na jedinstvo različitih znanstvenih disciplina, ne stvara li tada prostor i za filozofijski aspekt, odnosno ontološku razinu? To je uostalom nešto poput promotriti fenomen, kako je to razumio Einstein, s gledišta različitih referentnih sustava, premjestiti se na neko drugo stajalište, da bi iz te promjene stajališta uzmogli izvesti određene fizikalne posljedice, a u ovom slučaju razumjeti fenomen kao cjelinu (Cassirer, 1998, 63-64).

Na temelju svega iznesenog možemo zaključiti da tvar, kao pitanje prve faze emergencije složenosti, pokazuje kao primjer složenosti, odnosno tvar je po svim suvremenim shvaćanjima emergentni fenomen. Naime, prisjetimo li se temeljnih obilježja emergencije i emergnetnih fenomena, možemo zaključiti da se suvremeno razumijevanje tvari u potpunosti podudara $\mathrm{s}$ razumijevanjem $\mathrm{i}$ određenjem emergentnih fenomena. Naime, tvar upućuje na nemogućnost redukcije, što se u načelu smatra temeljnim preduvjetom da se nešto odredi kao emergentni fenomen. Jer, ako se fenomen ne može objasniti nekom fundamentalnijom sastavnicom, onda je riječ o emergentu (Bedau i Humphreys, 2008, 13). Nadalje, Hesenbergovo načelo neodređenosti, načelo komplementarnosti, odnosno razumijevanje tvari kao polja, izravno govore o nemogućnosti klasičnog predviđanja, a upravo se to obilježje nalazi u samom središtu ideje emergencije, što ujedno predstavlja podlogu novini fenomena i njegovoj neočekivanosti (Bedau \& Humphreys, 2008, 16). Nadalje, kako je to uočio već Einstein, ne postoje načini na koje bi se objasnila tranzicija iz subatomskog područja neodređenosti u makroskopsko područje dobro definiranih vrijednosti u odnosu na pozicije u prostor-vremenu (Norris, 2004, 121) pa je u tom smislu zaista riječ o jednom fenomenu koji nije u potpunosti objašnjiv. No, možemo dodati da suvremeno razumijevanje tvari upućuje na zaključak da je tvar emergentni fenomen koji se isključivo fizikalno ne može u potpunosti objasniti. Isto tako, s obzirom na to da je kauzalnost odozgo potvrđena na fundamentalnoj razini, a ona je obilježje emergentnih fenomena i u tom se smislu tvar pokazuje kao emergentni fenomen. Nadalje, s obzirom na to da se, kako kaže kopenhagensko tumačenje, na kvantnu razinu zbilje ne mogu primijeniti pojmovi klasične fizike, pojam tvari zaista predstavlja konceptualnu novost. Isto tako, s obzirom na to da razumijevanje tvari podrazumijeva uzimanje u obzir i ontološke razine fenomena, možemo reći da razumijevanje tvari potrebuje jedan holistički pristup. Dakle, tvar se uistinu može smatrati emergentnim fenomenom, a sva se ta obilježja mogu držati reflek- 
sijama dublje ontološke novine emergentnih fenomena, koja predstavlja i pozadinu i podlogu emergencije, ali i omogućuje njezino razumijevanje.

\section{Zaključak}

Da je prirodna stvarnost složena, čovjek je uočio davno i odmah je počeo tragati za njezinim temeljem. Tako su fundamentalnu razinu materijalnih bića pokušavali objasniti već prvi filozofi koji su tu temeljnu sastavnicu svega, tj. tvar, na koncu ipak mogli razumjeli samo s fizikalnog i metafizičkog aspekta. S razvojem znanosti pitanje složenosti zbilje postalo je sve aktualnije, a emergentni fenomeni sve uočljiviji pa je aktualno postalo i pitanje emergencije. Dapače, sama složenost i emergentni fenomeni upućuju na zaključak da se zbilja može tumačiti fizikalno i metafizički. Ipak, pozitivističko-redukcionističke tendencije imale su namjeru pokazati da se fundamentalna razina zbilje može objasniti iz konteksta fizike, a ako je tako, onda svaki govor o metafizici postaje u konačnici nepotreban, odnosno i emergencija složenosti može se razumjeti bez metafizičke razine. Suvremena znanost napokon se spustila na tu fundamentalnu razinu i došla do začuđujuće spoznaje: složenost postoji i na fundamentalnoj razini zbilje, a tvar ima neobična obilježja. Upravo iz detaljnijeg uvida u temeljna obilježja emergencije složenosti i suvremeno razumijevanje tvari dolazimo do sljedećih zaključaka: (1) tvar je emergentni fenomen, te se u tom smislu (2) fundamentalna razina prirode može razumjeti isključivo holistički, a to ujedno vodi do opravdanog zaključka da je (3) za razumijevanje brojnih razina emergencije složenosti nužno uzeti u obzir ontološku razinu emergencije složenosti. Naime, znanost može proučavati emergente, no odgovor na pitanje emergencije i realnosti emergenata može ponuditi samo filozofija. Brisanjem ontološkog vidika emergencije, odnosno sužavanjem zbilje na fizikalnu razinu ne možemo razumjeti fenomene koje sama znanost proučava. Drugim riječima, prva faza emergencije složenosti i suvremeno razumijevanje tvari upućuju na zaključak da tvar kao emergentni fenomen predstavlja poziv fizike na metafiziku.

\section{Literatura:}

Aristotel (1988). Fizika. Zagreb: Globus — Sveučilišna naklada Liber.

Aristotel (2001). Metafizika. Zagreb: Signum.

Bedau, Mark A.; Humphreys, Paul (ur.) (2008). Emergence: Contemporary Readings in Philosophy and Science. Cambridge: A Bradford book.

Byl, John (2007). Matter, Mathematics, and God. Theology and Science, 5(1), 73-86.

Cassirer, Ernst (1998). Uz Einsteinovu teoriju relativnosti: Spoznajnoteoretska razmatranja. Zagreb: Demetra.

Clayton, Philip D. (2004). Emergence: Us from it. U: John D. Barrow, Paul C. W. Davies i Charles L. Harper (ur.), Science and Ultimate Reality: Quantum Theory, Cosmology, and Complexity (str. 577-606). Cambridge: CUP.

Clayton, Philip D. (2010). Unsolved dilemmas: The concept of matter in the history of philosophy and in contemporary physics. U: Paul Davis i Niels H. Gregersen (ur.), 
Information and the Nature of Reality: From Physics to Metaphysics (str. 38-62). Cambridge: CUP.

Collingwood, Robin G. (1945). The Idea of Nature. London: Oxford.

Ellis, George F. R. (2004). True complexity and its associated ontology. U: J Paul C. W. Davies i Charles L. Harper (ur.), Science and Ultimate Reality: Quantum Theory, Cosmology, and Complexity (str. 607-636). Cambridge: CUP.

Fromm, Jochen (2004). The Emergence of Complexity. Kassel: Kassel University Press.

Heinemann, Gottfried (2009). Material und Supervenienz bei Aristoteles. U: Jochen Althoffet, Sabine Föllinger, Georg Wöhrle (ur.), Antike Naturwissenschaft und ihre Rezeption: Bd. 19 (str. 47-59). Trier: Wissenschaftlicher Verlag Trier.

Heisenberg, Werner (1997). Fizika i filozofija. Zagreb: KruZak.

Heisenberg, Werner (1998). Promjene u osnovama prirodne znanosti: Slika svijeta suvremene znanosti. Zagreb: KruZak.

Leibniz, Gottfried W. (1980). Izabrani filozofski spisi. Zagreb: Naprijed.

McMullin, Ernan (2010). From matter to materialism ... and (almost) back. U: Paul Davis i Niels H. Gregersen (ur.), Information and the Nature of Reality: From Physics to Metaphysics (str. 13-37). Cambridge: CUP.

McMullin, Ernan (ur.) (1965). The concept of matter in Greek and medieval philosophy. USA: University of Notre Dame.

Morowitz, Harold J. (2002). The Emergence of Everything: How the World became Complex. New York: Oxford University Press.

Naddaf, Gerard (2006). The Greek Concept of Nature. New York: SUNY.

Norris, Christopher (2004). Philosophy of Language and the Challenge to Scientific Realism. London: Routledge.

Pavlović, Branko U. (1978). Filozofija prirode. Zagreb: Naprijed.

Platon (1996). Fedon. Zagreb: Naklada Jurčić.

Poincaré, Henri (1989). Znanost i hipoteza . Zagreb: Globus.

Ridley, Brian K. (2001). On Science. London: Routledge.

Robinson, Howard M. (1974). Prime Matter in Aristotle. Phronesis, 19(2), 168-188.

Torretti, Roberto (1999). The Philosophy of Physics. Cambridge: CUP.

Zichichi, Antonino (2015). Complexity at the Fundamental Level of our Knowledge. U: Werner Arber, Jürgen Mittelstraß i Marcelo Sánchez Sorondo (ur.), Complexity and Analogy in Science: Theoretical, Methodological and Epistemological Aspects (str. 5789). Vatican City: Pontificiae Academiae Scientiarvm Acta 22.

Zovko, Nikola (2002). Prostor, vrijeme, tvar. Zagreb: ArTresor.

Žažar, Krešimir (2016). Konstrukt emergencije - epistemološki, teorijski i metodološki izazovi te praktične implikacije ispitivanja idejnog čvorišta raznorodnih socioloških perspektiva. Polemos, 19(1), 51-76. 
Substance - The Emergent Phenomenon and an Invitation from Physics to Metaphysics

\author{
Marina Novina*, Nikola Stanković**
}

\title{
Summary
}

The question of emergence complexity which cannot be reduced to that which precedes in nature is one of the most current concerns in multiple contemporary scientific disciplines and in philosophy. The issue of emergence complexity branches out into three basic questions (into the three so-called phases of emergence): whence all things emerge into being, whence life and whence consciousness? Already the first philosophers attempted to comprehend substance and considered substance an object to be studied by physics and metaphysics: this is the first phase of emergence complexity and it encompasses the attempt to grasp substance. However, contemporary science endeavours a reply from the sphere of physics. Furthermore, astonishing features of substance have been discovered which lead us to conclude that its reduction (to one) is not feasible, and that substance and its so-called fundamental level, known heretofore, are complex. This knowledge leads to the conclusion that understanding the material world is an issue of physics and metaphysics, that is, that the emergence concept presupposes and demands understanding on an ontological level. In this sense, it is important to see within a specific feature the conclusions to which the contemporary understanding of substance points. The aim of this paper is to explore the basic features of emergence and complexity, or rather the emergence of complexity, particularly the first phase of emergence and the contemporary understanding of substance and, based on this insight, to attempt to formulate an answer to the question: what is substance? If we are indeed dealing with the emergence phenomenon, what does this mean for our understanding of reality and the emergence of complexity in general?

Key words: emergence, complexity, emergence of complexity, first phase of the emergence of complexity, substance, emergent phenomenon, ontology, causality

* Marina Novina, mag. phil., soc., Faculty of Philosophy and Religious Studies, University of Zagreb. Address: Jordanovac 110, 10000 Zagreb, Croatia. E-mail: marina.novina@ffrz.hr

** Nikola Stanković, Ph.D., Full Professor — Retired, Faculty of Philosophy and Religious Studies, University of Zagreb. Address: Jordanovac 110, 10000 Zagreb, Croatia. E-mail: snikola@ffrz.hr 